\title{
Malaysian Community College Students Propensity to Venture into Entrepreneurship
}

\author{
Mohd Bekri Rahim ${ }^{1}$, Faizal Amin Nur Yunus ${ }^{1}$, Saiful Hadi Masran ${ }^{1}$, Jamil Abd Baser ${ }^{1} \&$ Mohd Fairuz Marian ${ }^{1}$ \\ ${ }^{1}$ Faculty of Technical and Vocational Education, University Tun Hussein Onn Malaysia, Malaysia \\ Correspondence: Mohd Bekri Rahim, Faculty of Technical and Vocational Education, University Tun Hussein \\ Onn Malaysia, Johor 86400, Malaysia. Tel: 60-7-456-4028. E-mail: bekri@uthm.edu.my
}

Received: August 21, 2013 Accepted: September 4, 2013 Online Published: November 29, 2013

doi:10.5539/ass.v9n17p232 URL: http://dx.doi.org/10.5539/ass.v9n17p232

\begin{abstract}
This study was conducted to identify the tendency of community college students choosing entrepreneurship as their career. The sample selected across the entire study population was composed of 103 final year students of Malaysia Community College. Four aspects of the study are to identify students interests, the characteristics of entrepreneurs, entrepreneurial knowledge and constraints faced by the students involved in entrepreneurial career. The approach used to collect data through questionnaires. The data collected was analyzed using descriptive statistical analysis using SPSS 15.0 (Statistical Packages for Social Science). Results showed that students have a high propensity for entrepreneurship and entrepreneurial features high in them. However, for entrepreneurship students have a moderate knowledge of entrepreneurship and constraints for high entrepreneurship. Therefore, it is suggested that collaboration between government agencies involved in entrepreneurship, parents, community and community colleges can be strengthened to help encourage students to venture into entrepreneurial careers.
\end{abstract}

Keywords: entrepreneurship, students interests, characteristics of entrepreneurs, entrepreneurial knowledge, constraints

\section{Introduction}

Entrepreneurship is defined as the overall attitudes, values, knowledge and skills that enable a person to be able to find, identify and seize the opportunity and translate its strategies and business efforts for economic benefit and profit (Bardai, 2000; Duval-Couetil, 2013; Spinelli \& Adam, 2012). Drucker (1996), in turn defines the entrepreneur as a person capable of transferring economic resources from the sector that lack productivity to the sector with higher productivity. The word entrepreneur is becoming popular in Malaysia in the mid-1970s in which the formulation and implementation of the New Economic Policy (NEP) was implemented and becoming more popular when Malaysian began to face the problem of unemployment among graduates.

The formation of a competitive and world class entrepreneur is a challenge in human resource development (Bosma \& Levie, 2010; Getz \& Petersen, 2005; Gompers et al., 2010). Malaysian government has provided a variety of programs and incentives to create competent entrepreneur, dynamic and possessing good business practices specifically to provide opportunities and comprehensive facilities to all segments of society. According to the Tenth Malaysia Plan, the government has been focusing on the development of human capital to emphasize on the help and support to increase the youth participation in the Small and Medium Enterprises (SMEs) and high-level enterprises (Economic Planning Unit, 2010). This clearly shows the government's determination to strengthen the entrepreneurial culture among the youth.

However, the graduates today are reluctant to choose entrepreneurship as a career (Greene, 2012; Potter, 2008). They still think that entrepreneurship does not guarantee their future as those that can be gained from working in the public or private sector. Therefore, it was not surprising that the number of unemployed youths in Malaysia, especially the indigenous group reached 36,000 as of December 2009 (Ministry of Human Resources, 2009). If the problem were not to be contained, the unemployment problem would become worse in the event that career focus were solely on the public and private market that had become ever more limited. The students need to be exposed and encouraged to enter the field of entrepreneurship from an early stage, starting from the educational institutes (Dabbagh \& Menasce, 2006; Mellor, 2008).

Community colleges are institutions that provide education opportunity, training need and skill to all local 
communities before going to the labour market through education and technical training and vocational and lifelong learning (Department of Community Colleges, 2010). In addition, community colleges also focused on the needs of the local community in order to reduce the migration of rural youth to urban areas in search of jobs. Through the knowledge and skills learned indirectly provide opportunities for youths to work on their own with the opening of entrepreneurship through business premises such as repairing motorcycles, televisions, computers and so on. Even the role of community colleges in the development of entrepreneurship become increasingly important and has the potential to provide a more meaningful way to students, employers and the local community.

Globally, community college is a platform that is responsible in providing human resource training and entrepreneurship in the effort of developing national economy (NACEE, 2013). This is in line with Malaysia's vision of community colleges as centres of excellence in the fields of technology, business and industrial services, and responsible to produce graduates who are competent, honourable and responsible in line with the national education philosophy (Department of Community Colleges, 2010). Various efforts have been undertaken by the government in promoting entrepreneurship among students. The characteristics of entrepreneurs and students knowledge about entrepreneurship should be noted besides exposing them to business opportunities that should be seized (Kuratko, 2012; Oakey et al., 2002; Von Graevenitz et al., 2010). Constraints that are faced to be involved in entrepreneurship should be studied and solved. Hence this study was undertaken to: (i) identify the tendency of students to become entrepreneurs, (ii) identify the characteristics of entrepreneurship that is presence on students, (iii) identify the level of entrepreneurial knowledge possessed by students and (iv) identify the constraints faced by students in participation as entrepreneurs.

\section{Method}

Descriptive research using questionnaires as research instruments were used in conducting this study. Descriptive study is selected because of its comprehensive characteristics regarding the issues or problems, fast data collection, the use of large sample sizes, the information collected directly from respondents in a short time and the results of this study can be generalized to a certain population study (Check \& Schutt, 2012; Cohan et al., 2011). Even the survey was able to measure the variables to be measured from a large sample size with high precision and a small sampling error (Kumar, 2011). A total of 103 final-year students at Malaysia Community Colleges have been involved as a sample in this study representing the entire study population. For the purpose of getting high validity and reliability, the number setting of samples are based on Krejie and Morgan sample size determination schedule (1970), where if the population size is 140 , the minimum sample size used is 103 . This study used questionnaires in the form of five-point Likert scale ( $1=$ strongly agree; $5=$ strongly disagree $)$ and for gathering information, the researchers have distributed themselves the set of questionnaires to students. By this method, the researchers can explain to respondents the method used to answer the survey form. In determining the content validity of the questionnaire built, the service of three experts from Community College lecturers has been used. Level of reliability of questionnaires was obtained by conducting a pilot study before implementing the actual study. A pilot study was conducted on 30 students ranging from actual samples of the study. Data from 30 samples was analyzed using SPSS through Realibility Analysis-Scale Alpha Cronbach. According to Numally (1978), the alpha value of 0.70 to 0.90 is an acceptable range of values that enable the instrument to be used in the research. Overall Cronbach Alpha values obtained for each item is 0.8 to 0.9 , this means that the instruments used are valid and appropriate. The data obtained were analyzed to get the mean value using Statistical Package for the Social Sciences (SPSS) version 15.0.

\section{Results}

The findings on the tendency of students to venture into entrepreneurial careers are presented through Table 1. In total the students have a high propensity to become an entrepreneur. 
Table 1. The tendency of students to venture into entrepreneurship

\begin{tabular}{|c|c|c|c|c|}
\hline No. & Item & Mean & $\begin{array}{l}\text { Standard } \\
\text { deviation }\end{array}$ & Interpretation \\
\hline 1 & I prefer to be self-employed compared to being wage earner & 3.92 & 0.957 & High \\
\hline 2 & I would like to have my own business & 4.18 & 0.988 & High \\
\hline 3 & I plan to venture into entrepreneurship & 4.11 & 0.839 & High \\
\hline 4 & I like to do something that can bring financial gain & 4.44 & 0.904 & High \\
\hline 5 & $\begin{array}{l}\text { I like to follow a story related to a person's success in } \\
\text { entrepreneurship }\end{array}$ & 3.98 & 0.980 & High \\
\hline 6 & $\begin{array}{l}\text { I'm always looking for information on entrepreneurship in mass } \\
\text { media such as the internet, magazines, and newspapers }\end{array}$ & 3.56 & 0.946 & High \\
\hline Total & & 4.03 & 0.661 & High \\
\hline
\end{tabular}

While the findings of the study on the characteristics of entrepreneurial owned by the students to venture into entrepreneurial careers are presented by Table 2. Besides the tendency to venture into entrepreneurship, the students are also found to possess high entrepreneurial characteristics in themselves.

Table 2. Entrepreneurial characteristics possessed by students

\begin{tabular}{lllll}
\hline No. & Item & Mean & $\begin{array}{l}\text { Standard } \\
\text { Deviation }\end{array}$ & Interpretation \\
\hline 1 & Competition motivates me to work harder & 4.15 & 0.821 & High \\
2 & I am willing to face risk in order to achieve success & 4.17 & 0.830 & High \\
3 & Failure motivated me to keep trying & 4.17 & 0.830 & High \\
4 & I am responsible for the tasks assigned to me. & 4.28 & 0.706 & High \\
5 & Time management is very important for me when doing a job & 4.35 & 0.776 & High \\
6 & I always make a plan before doing any work & 4.20 & 0.784 & High \\
7 & I'm ready to add the skills, ability and knowledge to venture & 4.30 & 0.739 & High \\
Total & into entrepreneurship & 4.23 & 0.597 & High \\
\hline
\end{tabular}

Results of the analysis findings regarding the knowledge possessed by the students regarding entrepreneurship is as shown by Table 3 . The results of the analysis show that the students generally possess and average level of entrepreneurship knowledge.

Table 3. Entrepreneurial knowledge possessed by students

\begin{tabular}{|c|c|c|c|c|}
\hline No. & Item & Mean & $\begin{array}{l}\text { Standard } \\
\text { Deviation }\end{array}$ & Interpretation \\
\hline 1 & I know how to prepare a business plan. & 2.21 & 0.839 & Low \\
\hline 2 & I know the risk that would be faced by an entrepreneur. & 4.06 & 0.861 & High \\
\hline 3 & I know the skills that are needed to be an entrepreneur. & 3.87 & 0.893 & High \\
\hline 4 & $\begin{array}{l}\text { I know the government agency that is involved in business } \\
\text { capital financing. }\end{array}$ & 2.25 & 0.837 & Low \\
\hline 5 & $\begin{array}{l}\text { I know the government agency that is involved in advisory } \\
\text { and business training. }\end{array}$ & 2.15 & 0.879 & Low \\
\hline 6 & $\begin{array}{l}\text { I know the type of business ownership that exists in } \\
\text { Malaysia }\end{array}$ & 3.47 & 0.905 & Moderate \\
\hline 7 & $\begin{array}{l}\text { I know that the environmental influence plays an } \\
\text { important role in the selection of the business type. }\end{array}$ & 3.88 & 0.820 & High \\
\hline Total & & 3.13 & 0.597 & Moderate \\
\hline
\end{tabular}


Constraints faced by the students to become entrepreneurs were also analyzed and presented through Table 4 . Overall, it was found that the students faced high constraints when venturing into entrepreneurship.

Table 4. Constraint in venturing into entrepreneurship

\begin{tabular}{lllll}
\hline No. & Item & Mean & $\begin{array}{l}\text { Standard } \\
\text { Deviation }\end{array}$ & Interpretation \\
\hline 1 & I have no basic knowledge in the business world & 4.21 & 0.839 & High \\
2 & My family kept me from going into business & 1.62 & 0.861 & Low \\
3 & I do not know how to get capital assistance to start a business. & 4.33 & 0.893 & High \\
4 & I feel that my age is too young to be an entrepreneur. & 2.11 & 0.837 & Low \\
5 & I lack confidence to start my own business. & 4.13 & 0.879 & High \\
6 & I lack the skills to manage my own business. & 4.23 & 0.905 & High \\
7 & Being involved in entrepreneurship disturb my daily schedule & 2.93 & 0.820 & Low \\
Total & & 3.36 & 0.398 & High \\
\hline
\end{tabular}

\section{Discussion}

\subsection{Students Tendency to Be Involved in Entrepreneurship}

The findings show that the tendency level of Malaysia Community College's students to be involved in entrepreneurship as a whole is high. The majority of students tend to become entrepreneurs. Tendency for students to become entrepreneurs who have gotten the most positive feedback by respondents are they likely to do something that can bring financial gain. A successful entrepreneur is certainly willing to run the risk of making a change or jobs that can bring profits. Tendency for students to become entrepreneurs can also be seen from their high feedbacks to own their own business. This is in line with the college's intention to produce promising entrepreneur and students with the ability to start their own business after graduation. Oakey et al. (2002) argues, students' participation in entrepreneurship can provide a big impact on a country's industrial development.

The students are also found to have high interest and plan to venture into entrepreneurship. This is in line with the Ministry of Entrepreneur and Cooperative Development (MeCD) to encourage people to make entrepreneurship as a career option. The government also sought to reduce unemployment and increase employment opportunities for the graduates by encouraging them to become entrepreneurs (PUNB, 2013). Therefore, based on the arguments presented, it can be concluded that the final year students of Malaysia Community College has a high propensity to become an entrepreneur.

\subsection{Entrepreneurial Characteristics Possessed by Students}

The majority of respondents agreed that they have the characteristics of entrepreneurship in them. Entrepreneurial characteristic that have the highest feedback are characteristics regarding systematic planning. According to Von Graevenitz et al. (2010) an entrepreneur who is able to make a good and systematic planning in order to achieve business goals has a high potential for success. He added that good planning taking into account the internal analysis (strengths and weaknesses), the external analysis (opportunities and threats) and detailed information.

Malaysia Community College students also have the entrepreneurial characteristics of high ability to find information. According to Duval-Couetil (2013) attributes to become a competent entrepreneur is a tendency to make informed decisions to achieve goals or solve business problems. In fact, an entrepreneur should be wise in finding and filtering information for business benefit. Potter (2008) also agreed and said that entrepreneurship is closely related to global economy changes that are growing and changing rapidly, hence it is necessary for an entrepreneur to possess the features and the ability to use information that is useful to be able to survive in this industry.

Commitment to the work agreement is also among the important characteristics of entrepreneurship and has a high value feedback from the respondents. Commitment to an agreement is one of the positive values that are able to encourage the success of an entrepreneur. A committed entrepreneur would be able to give priority to 
ensure the task is completed in accordance with the agreement and take full responsibility for any problems with the customer (Kuratko, 2012). On the whole it can be concluded that the final year students Malaysia Community College has high entrepreneurial characteristics in them.

\subsection{Level of Entrepreneurial Knowledge Possessed by Students}

Level of entrepreneurial knowledge possessed by final year students of Malaysia Community College on the whole is average. However, there are some question items that have high knowledge value which includes knowledge regarding the risk that would be faced by the entrepreneurs, skills needed to become an entrepreneur and also knowledge about the influence of the environment that plays an important role in the selection of the type of business.

Knowledge of the risk to be taken by an entrepreneur is important and courage to take risks need to be balanced with the knowledge and understanding of how to assess and manage the risks involved (Spinelli \& Adam, 2012). Knowledge of an entrepreneur should also cover all aspects of the business, including human resources, capital, products, markets, supplies, equipment and technology (Kuratko, 2012; Spinelli \& Adam, 2012). Skills needed to become an entrepreneur are also important in determining the success of any business carried on (Deakins \& Freel, 2012).

However, there are also items that have a low value of knowledge among students, which includes the knowledge to prepare business plans, government agencies involved in business capital financing, and government agencies involved in business advisory and training services. Verily the knowledge and experience should go hand in hand. Thus, the knowledge to start and improve the business should be learned to create a more competitive young entrepreneur. Entrepreneurial knowledge will help the entrepreneurs to develop their business, helping entrepreneurs take advantage of a good business opportunity and increase their self-confidence (Hatten, 2012).

\subsection{Level of Constraints to Venture into Entrepreneurship}

Constraints faced by the students to venture into entrepreneurship as a whole is high. Internal constraint faced by the students such as lack of self-confidence, lack of knowledge on how to gain business capital, lack of business management skills and no basic knowledge in business are high.

These constraints can be overcome if the students are exposed by agencies that could aid them as a young entrepreneur. The community college should play a role in opening students' minds to their potential and business opportunities that should be grabbed. This is consistent with the statement of Greene (2012) which states that to start and expand a business, an entrepreneur needs to find, evaluate and choose a viable business opportunity, have to have a vision of themselves, and be able to gather information resources, knowledge and entrepreneurial skills.

However, the majority of respondents are found not to face external constraint that is from the family. The students do not face any obstacles from the family if they are serious about going into business. Family supports play an important role and influence the entrepreneurial career development that is ventured by the entrepreneur (Getz \& Petersen, 2005; Zahra et al., 2004). Overall, the students face high internal constraints that are regarding self-ability to venture into entrepreneurship and low external constrains that is obstacles from the family.

\section{Conclusion}

Overall findings of the study found that the final year students of Malaysia Community College have a high propensity to become an entrepreneur. In addition, the study also found that students have the characteristics of entrepreneurship in them. However, to venture into entrepreneurship the students have moderate knowledge of entrepreneurship and high constraints to venture into entrepreneurship.

Malaysia Community College can help the students enhance their knowledge of entrepreneurship by organizing entrepreneurial programs involving cooperation of government agencies involved in the financing business capital, advisory services and business training to students. Entrepreneurship Course organized by the Ministry of Higher Education Malaysia (MOHE) can also be established at Community College so that the students can be exposed to the basic skills of entrepreneurship. KPTM side can enhance the entrepreneurship modules to encourage community college graduates to venture into entrepreneurship. Entrepreneurship module must be added to the current knowledge elements of the agency that provides business capital and business advisory services and training. In fact, aspects such as self-confidence skills, punctuality, enthusiasm and creativity can also be inserted in the module.

Students should also gain knowledge on the characteristics of entrepreneurs and career information as 
entrepreneur to help the students evaluate their potential to become entrepreneurs. The student should receive disclosure of the risks that lie ahead, and to strengthen the skills of entrepreneurship. Armed with adequate knowledge and skills, are expected to train student interest and creativity in enhancing the country's productivity and contribute to the national economy.

\section{References}

Bardai, B. (2000). Keusahawanan dan Perniagaan. Kuala Lumpur: Dewan Bahasa Dan Pustaka.

Bosma, N. S., \& Levie, J. (2010). Global Entrepreneurship Monitor 2009. Executive Report.

Check, J., \& Schutt, R. K. (2012). Research Methods in Education. Sage Publications Inc.

Cohan, L., Manion, L., \& Morrison, K. (2011). Research Methods in Education (7th ed.). Routledge.

Dabbagh, N., \& Menascé, D. A. (2006). Student perceptions of engineering entrepreneurship: An exploratory study. Journal of Engineering http://dx.doi.org/10.1002/j.2168-9830.2006.tb00886.x

Deakins, D., \& Freel, M. (2012). Entrepreneurship and Small Firms. Sixth Edition. McGraw Hill.

Department of Community Colleges. (2010). Mission and Vision Community Colleges. Retrieved June 1, 2013, from http://www.jpkk.edu.my/jpkk/

Drucker, F. P. (1996). Entrepreneurship. Pan Business Management.

Duval-Couetil, N. (2013). Assessing the impact of entrepreneurship education programs: Challenges and approaches. Journal of Small Business Management, 51(3), 394-409. http://dx.doi.org/10.1111/jsbm.12024

Economic Planning Unit. (2010). Tenth Malaysia Plan 2011-2015.

Getz, D., \& Petersen, T. (2005). Growth and profit-oriented entrepreneurship among family business owners in the tourism and hospitality industry. International Journal of Hospitality Management, 24(2), 219-242. http://dx.doi.org/10.1016/j.ijhm.2004.06.007

Gompers, P., Kovner, A., Lerner, J., \& Scharfstein, D. (2010). Performance persistence in entrepreneurship. Journal of Financial Economics, 96(1), 18-32. http://dx.doi.org/10.1016/j.jfineco.2009.11.001

Greene, C. L. (2012). Entrepreneurship: ideas in action. Fifth Edition. South-Western Cengage Learning.

Hatten, T. S. (2012). Small business management: entrepreneurship and beyond. Fifth Edition. South-Western Cengage Learning.

Krejcie, R. V., \& Morgan, D. W. (1970). Determining sample size for research activities. Educ. Psychol. Meas.

Kumar, R. (2011). Research Methodology: A Step-by-Step Guide for Beginners (3rd ed.). SAGE Publications inc.

Kuratko, D. F. (2012). Entrepreneurship: Theory, process, and practice. South-Western Pub.

Mellor, R. (2008). Entrepreneurship for everyone: A student textbook. SAGE Publications Limited.

NACEE. (2013). National Association for Community College Entrepreneurship. Retrieved June 3, 2013, from http://www.nacce.com/

Numally, J. C. (1978). Psychometric theory. NY: McGraw-Hill.

Oakey, R. P., Mukthar, S. M., \& dan Kliping, M. (2002). Student perspectives on entrepreneurship: Observations on their propensity for entrepreneurial behaviour. International Journal of Entrepreneurship and Innovation Management, 4-5(2), 308-322. http://dx.doi.org/10.1504/IJEIM.2002.000487

Potter, J. (2008). Entrepreneurship and Higher Education. OECD Publishing, Paris.

PUNB. (2013). Program Siswazah Perantis PUNB. Retrieved June 1, 2013, from http://www.punb.com.my/index.php?ch=bm_pros\&pg=bm_prog_siswa_per\&ac $=151$

Spinelli, S., \& Adam, R. (2012). New venture creation: entrepreneurship for the 21st century (9th ed.). McGraw-Hill.

Von Graevenitz, G., Harhoff, D., \& Weber, R. (2010). The effects of entrepreneurship education. Journal of Economic Behavior \& Organization, 76(1), 90-112. http://dx.doi.org/10.1016/j.jebo.2010.02.015

Zahra, S. A., Hayton, J. C., \& Salvato, C. (2004). Entrepreneurship in family vs. Non-family firms: a resource-based analysis of the effect of organizational culture. Entrepreneurship theory and Practice, 28(4), 363-381. http://dx.doi.org/10.1111/j.1540-6520.2004.00051.x

\section{Copyrights}

Copyright for this article is retained by the author(s), with first publication rights granted to the journal.

This is an open-access article distributed under the terms and conditions of the Creative Commons Attribution license (http://creativecommons.org/licenses/by/3.0/). 